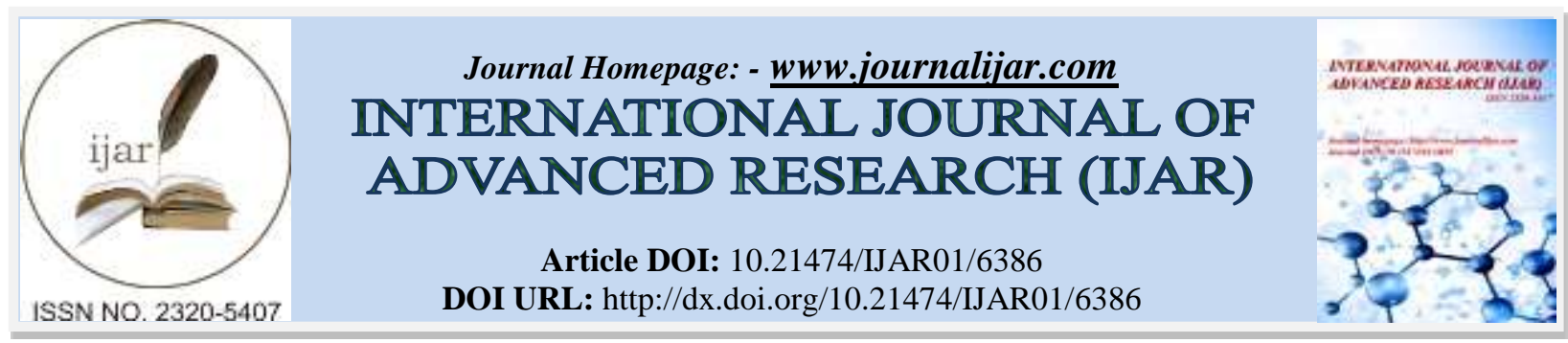

RESEARCH ARTICLE

\title{
THE LEVEL OF CONTENT FEASIBILITY OF VGM REPRESENTATION-BASED PHYSICS TEXTBOOK AFTER BEING USED IN THE LEARNING PROCESS
}

\author{
I Ketut Mahardika, Azimatun Ni'mah Hasan, Yushardi, Sutarto, Nuriman, Suratno, and Indrawati. \\ University of Jember, Jember, Indonesia 68121.
}

\section{Manuscript Info}

Manuscript History

Received: 22 November 2017

Final Accepted: 24 December 2017

Published: January 2018

Key words:-

Content feasibility, Physics textbook, VGM representation.

\begin{abstract}
This article discussed the level of the content feasibility of VGM representation-based Physics textbook. By using this textbook, students were required to have deep understanding about the concept of Physics in daily life in terms of verbal, image and mathematical representation. The objective of the research was to know the level of the content feasibility of VGM representation-based Physics textbook after being used in the learning process. This research was a development research. The subjects of the research were VIII graders of MTs Negeri 3 Jember. The technique of data collection was in the form of test. The technique of data analysis was using the $\mathrm{N}$-gain formula for pre-test and post-test scores. The results showed that based on the level of the content feasibility of Physics textbook, students' output after the learning process was on the valid criteria. In addition, based on the average results, $\mathrm{N}$-gain indicated for high criteria.
\end{abstract}

Copy Right, IJAR, 2018,. All rights reserved.

\section{Introduction:-}

Science learning in Junior High School (SMP/MTs) necessarily encourages and facilitates students to construct their knowledge based on constructivism philosophy. Students are expected to comprehend and apply the knowledge (factual, conceptual, and procedural) through meaningful learning. Meaningful learning in science education has an important role in improving educational quality in accordance with the challenges of education in globalization era. One of the most important parts of science is Physics. According to Druxes (1986: 3), physics is a lesson about natural events that allows a research by systematic experiment and testing based on general rules. The nature of Physical science covers two parts including Physics as a product and Physics as a process. Physics as a product includes a collection of knowledge consisting of facts, concepts, and principles of Physics. Physics as a process includes the skills and attitudes of the scientists to acquire and develop Physics products. These skills are process skills, while the attitudes of the scientists are known as scientific attitudes (BSNP, 2006).

Physics learning is not only taught to students in the form of facts and concepts but the students are also trained in finding facts and concepts through scientific processes and attitudes. It allows Physics learning in schools in line with the implementation of the 2013 curriculum that uses Scientific Approach in the learning process (BSNP, 2014). Scientific Approach is approximately a learning process that guides students to solve the problems through careful planning, careful data collection, and careful data analysis to draw a conclusion (Abidin, 2014). The learning of Scientific Approach encourage students to think critically, analytically and appropriately in identifying, understanding, solving the problems, and applying the learning materials (Hosnan, 2014). 
Based on the interview with the teachers of science grade 9 MTsNJember, in the learning process, the teacher was still dominant while the students were lack of access to develop independently through the meaningful learning. The teachers had not yet facilitated the students to learn independently. This result indicated that teachers had not created their own teaching materials and still used BSE books or Student Activity Book (LKS) which were purchased from commercial publishers. In addition, the problems faced by teachers in learning were: (1) teachers of Physics were not much knowing innovative learning media and were having problem in finding the appropriate strategy in order to make students with low competences can actively learn with limited learning facilities and resources, (2) the level of Physics teacher competence were not sufficient in developing student learning media, and (3) the limitation of time for Physics teachers to be able to provide interesting learning media in solving student's problems. Therefore, learning media that can train and improve student learning outcomes were required.

One of the learning media that can support the learning process is a textbook. Textbook is a book that is used as a course book in a particular field of study which is a standard book compiled by the experts in the related fields for instructional purposes and objectives. It is complemented by harmonized and understandable teaching tools by the users in the schools and colleges in order to support the teaching program (Suharjono, 2008: 83). Mahardika (2012: 23) mentioned that the book as a teaching material is a book that contains a science of analysis results about the curriculum in the written form. A good textbook, according to Situmorang (2013), should be able to motivate the learners by making use of interesting things such as pictures, illustrations, and case examples, in addition, have sufficient material to support teaching and learning process, and can be used to support problem-solving activities. The material in the textbook is the realization of the material listed in the curriculum. Some requirements that are required in making the book as a learning resource are: easy access for the students, material effectiveness and meeting the needs of students who consider themselves as independent learners (Nursamsudin, 2017).

Textbooks that can train and improve student learning outcomes should use the right approach. One of the approaches that can be used is the multi-representation approach because in Physics learning students are required to master different representations, for example: experiment, graph, conceptual, formula, figure, and diagram (Mahardika, 2013). VGM representation is one variation of multi-representation approach. The representations include verbal representation, image representation, and mathematical representation. The strength of VGM Representation is to have verbal representation in the beginning then it is followed by image and mathematical representations. Verbal representation at the beginning of the discussion of the material will attract and arouse students' curiosity to know the application concept of the learning material. A great curiosity will guide students in reading the image and mathematical representations which are presented after the verbal representation.

VGM representation-based Physics textbook is designed for students in order to solve Physics problems with verbal, image, and mathematical representation processes so that the Physics concept can be well comprehended. In making Physics learning materials in the form of Physics textbook, one important aspect that must be considered is the content feasibility of the textbook. The content feasibility of VGM representation-based Physics textbook includes the alignment with the standard competence and basic competence of the lesson, the alignment with child development and community needs, scientific substance and life skills, insights to move forward and develop, and diversity of social values. The content feasibility is important to be considered so that the concept of Physics can be well comprehended.

The results of the research by Widianingtiyas (2015) showed that a research using multi-representation approach in Physics learning can improve students' cognitive ability. Critical thinking skills are one of students' cognitive abilities. Reciprocally, a research conducted by Mahardika (2013), showed a significant influence between student learning outcomes applying the model of multi-representation-based Quantum Teaching with direct instruction model in Physics in high school. Based on the description, the research problem is how the level of the content feasibility of VGM representation-based Physics textbook after being used in the learning process.

\section{Research Method:-}

This research can be categorized as educational research development which was the development of VGM representation-based Physics textbook. Research development is a research that aims to develop a product through a series of trials and revisions in order to get feasible results or products (Ramadhani, 2016). The product of this development research was VGM representation-based Physics textbook. The design of this research was one group pretest-posttest design. This design used a group of samples that were purposely selected and then were given the treatment of pre-test (initial test) $\mathrm{O} 1$ which was followed by giving the treatment $\mathrm{X}$. at the end of the learning 
process, the samples were given post-test (final test) $\mathrm{O} 2$. The data collection techniques used by researchers in this textbook development research were test, observation, interview, and documentation. The content feasibility of the textbook could be seen from the result of logic validation in the form of responses of two post-graduate lecturers and one senior teacher of science in Physics about the content of VGM representation-based Physics textbook and empirical validation through the improvement of students' VGM representation ability. Based on the objective of this research, to test the average of cognitive skills improvement in the form of student learning outcomes, the data were tested by using N-gain formula. In addition, the subjects of the research were VIII graders of MTs Negeri 3 Jember.

\section{Findings and Discussion:-}

This research was a development research that aimed to obtain a product of Physics teaching materials in the form of VGM representation-based Physics textbook. This VGM representation-based Physics textbook consisted of three learning activities of each material, including vibrations, transversal waves, and longitudinal waves. The first page contained the title of VGM representation-based Physics textbook, the educational level to the use of VGM representation-based Physics textbook and textbook compilers. Moreover, the pages of each textbook contained the title of the learning materials including vibrations, transversal waves, and longitudinal waves. The introduction contained the standard competence and the basic competence of each material, the instructions on using the textbook, and map concept. The table of contents included the content of VGM representation-based Physics textbook and its pages. The learning activities included apperception, student activities, explanation of material concepts, sample questions, exercise questions and test of learning outcomes. The key answers contained key answers to the exercise questions and the test of learning outcomes of each learning activity. The references contained the literature sources that were used in the compilation of VGM representation-based Physics textbook.

Logic validation result data of content validity of natural science-physics textbook based on VGM representation is obtained from validation assessment of content validity of natural science-physics textbook based on VGM representation by three validators who natural science education expert. Validation result of content validity of natural science-physics textbook based on VGM representation can be seen on table 1 .

Table 1:- Criteria content validity based on VGM representation by three validator

\begin{tabular}{|c|c|c|c|c|c|c|}
\hline \multirow[t]{2}{*}{ No } & \multirow[t]{2}{*}{ Assessment of content validity } & \multicolumn{3}{|c|}{ The result of assessment } & \multirow[t]{2}{*}{ Average } & \multirow[t]{2}{*}{ Criteria } \\
\hline & & Val. 1 & Val. 2 & Val. 3 & & \\
\hline 1 & Alignmentwith KI and KD & 3 & 4 & 4 & 91,6 & Valid \\
\hline 2 & $\begin{array}{rr}\text { Alignmentwith children development and } \\
\text { society need }\end{array}$ & 3 & 4 & 4 & 91,6 & Valid \\
\hline 3 & Knowledge substance andlife skills & 3 & 4 & 3 & 83,3 & Valid \\
\hline 4 & Perception for progress and develop & 3 & 3 & 3 & 75 & Enough \\
\hline 5 & Variety social values & 3 & 4 & 4 & 91,6 & Valid \\
\hline & Total & $75 \%$ & $95 \%$ & $90 \%$ & $86,6 \%$ & Valid \\
\hline
\end{tabular}

The level data of content validity of students' natural science - physics textbook is obtained from alignment with competence standard and basic competence, Alignmentwith children development and society need, knowledge substance and life skill, perception for progress and develop, and Variety social values.

The result data of students VGM representation ability is used for knowing the improvement students achievement in cycle 1 , cycle 2 , and cycle 3 , as support data for content validity of natural science - physics textbook based on VGM. The score of students' VGM representation ability (pre-test and post-test) for each cycle can be seen on table 2 .

Table 2:- The achievement test use natural science-physics textbook based on VGM representation

\begin{tabular}{|c|c|c|c|}
\hline \multirow{2}{*}{ No. } & Cycle & \multicolumn{2}{|c|}{ Score Average } \\
\cline { 3 - 4 } & & Pre-test & Post-test \\
\hline 1 & Cycle 1 & 21.04 & 79.92 \\
\hline 2 & Cycle 2 & 16.58 & 83.00 \\
\hline 3 & Cycle 3 & 22.85 & 83.00 \\
\hline
\end{tabular}


Then, the score average of students' VGM representation ability is used for knowing the improvement students achievement use natural science-physics textbook based on VGM representation through N-gain which shown by table 3 .

Table 3:- The result of N-gain

\begin{tabular}{|c|c|c|c|}
\hline No. & Cycle & N-gain & Category \\
\hline 1 & Cycle 1 & 0.619 & medium \\
\hline 2 & Cycle 2 & 0.700 & high \\
\hline 3 & Cycle 3 & 0.780 & high \\
\hline \multicolumn{2}{|c|}{ Average } & 0.700 & high \\
\hline
\end{tabular}

This research result is a product for content validity of natural science-physics textbook based on VGM representation in grade VIII MTs Negeri 3 Jember. The quality of natural science-physics textbook based on VGM representation which valid category is natural science-physics textbook which already though on expert validation (logic). The average validity assessment result is $86,6 \%$, so it can be used for developing test in the class. The developing step for natural science-physics textbook based on VGM representation are expert validation (logic) and developing test. The expert validation process is implemented before researcher do the developing test. The expert validation process to content validity component for natural science-physics textbook based on VGM representation is done by three validators. During validation process, several revision has done for the component of natural science-physics textbook based on suggestion and critic from validator. The validation process done because there are still weaknesses and error which need to repair on textbook in order to get a natural science-physics textbook based on VGM representation with valid category.

On the expert validation process, obtained data that validator give suggestion to complete natural science-physics textbook based on VGM representation from two topic become one semester, add exercise item for each learning activity, repair the color of sub topic, word choice and punctuation, and several concept especially the picture presentation. Based on expert validation, obtained conclusion that natural science-physics textbook based on VGM representation can be used by small revision. The developing test is implemented to students grade VIII MTs Negeri 3 Jember on odd semester academic year 2017/2018, by using pre-experimental one-group pretest-posttest design, it is research design which use one respondent group and then take students achievement test data before action (pretest), and after action (post-test). The developing test is implemented by three cycles. The topic in First cycle is vibration. The second cycle is transverse wave. And the third cycle is longitudinal wave. Each learning activity was done observation by three observers from teacher of MTs Negeri 3 Jember.

The developing test was done empirical validation to content validity natural science-physics textbook based on VGM representation. The data obtained when empirical validation is the improving students achievement VGM representation which used to asses content validity of natural science-physics textbook based on VGM representation. The assessment result from expert validation show that content validity component namely alignment to competence standard and basic competence, alignment with children development and society need, knowledge substance and life skill, perception to progress and develop, and variety social values is $86,6 \%$ and valid category. And the result of developing test is shown by increasing students achievement VGM representation ability which analyzed by $\mathrm{N}$-gain for each cycle. First cycle, N-gain is 0.619 and include in medium level. First cycle is medium category because students didn't use textbook. Before doing the second cycle, we did evaluation and reflection to first cycle in order to make better for the next learning. In second cycle, $\mathrm{N}$-gain was 0.700 and include in high category. It can be reached because students has understood how to use natural science - physics textbook based on VGM representation. Third cycle was implemented to ensure the result from second cycle. N-gain for third cycle was 0.780 and high category. $\mathrm{N}$-gain that obtained in third cycle is higher than second cycle. One of effect is caused material character which used in third cycle was longitudinal wave. This material is easier and simple than transverse wave which used in second cycle.

It can be described that implementation science-physics learning by natural science-physics textbook based on VGM representation can increase students' cognitive skill generally. 


\section{Discussion:-}

This research is part of developing research for natural science-physics textbook based on VGM representation. This research purpose to know content validity level of natural science-physics textbook based on VGM representation (verbal, figure, mathematics). To reach the purpose, it was done trial by using direct instruction learning by natural science-physics textbook based on VGM representation as primary study source. Implementation direct instruction learning ask teacher to oriented in class such as material presentation and students only write and listen to teacher. But in this research, the role of teacher is substituted by natural science-physics textbook based on VGM representation. This direct instruction learning model was used to decrease the role of teacher in learning, and maximize the role of natural science-physics textbook based on VGM representation to increase students' cognitive skill.

Learning use natural science-physics textbook based on VGM representation, it causes students to active in learning based on material feature. The feature on textbook is begun by verbal representation to appear students' curiosity and increase students' motivation to know content of material. It is continued by figure representation which can help students' comprehension the meaning of verbal representation. Mathematic representation is given after verbal and figure representation to help students comprehension deeper on textbook. Material is used in this research is vibration and wave.

Based on research result, researcher suggest to the next research in learning process must focus to language validity aspect and presentation to support success of content validity natural science-physics textbook based on VGM representation.

\section{Conclusion:-}

Based on the result and discussion can be concluded content validity level of natural science-physics textbook based on VGM representation after implemented in learning is valid and based on average $\mathrm{N}$-gain is high.

\section{Bibliography:-}

1. Abidin, Y. 2014. Design of Learning Systems in the Context of Curriculum 2013. PT RefikaAditama: Bandung.

2. BSNP. 2006. Guidance of Curriculum Development at Level of Education Level of Basic and Secondary Education. Jakarta: Kemdikbud.

3. BSNP. 2014. Curriculum 2013 High School / Madrasah Aliyah. Jakarta: Kemdikbud.

4. Druxes, H; Born, Gernot; Siemsen, F. 1986. Compendium Didakik Physics. Bandung: RemajaKarya

5. Facione, Peter A. 2011. Critical Thinking: What It is and Why it Counts. California: The California Academic Press

6. Hosnan, M. 2014. The Scientific and Contextual Approach in 21st Century Learning. Ghalia Indonesia: Bogor.

7. Kadarmanto, A., dkk. 2017. Validity of basic physics module of CAC model to improve higher order thinking skills of college students. International Journal of Advanced Research (IJAR). No. 5. Vol. 10: 1293-1298.

8. Mahardika, I. K. 2012. Representation of Mechanics in Discussion. Jember: UPT Publishing UNEJ.

9. Mahardika. 2012. Model inquiry to improve the ability of verbal and mathematical representation in physics learning in senior high school. Journal of Physics Learning. Volume 1, Nomor 2, September 2012.

10. Mahardika, I. K. 2013. Implementation of conceptual interactive learning model to improve the ability of verbal, mathematical, and physics representation of Grade VIII-A students MTs N 1 Jember 2012/2013. Journal of Physics Education, No. 2. Vol3: 272-277.

11. Nursamsudin, I., dkk. 2017. The Development of Chemical Impacts Based on Drawing Processes on Electrolite and Non-Electrolite Materials for Learning in SMA. The International Journal of Sciences and Humanities Invention 4(11): 4098-4105.

12. Ramadhani, W.P. 2016. Components of Feasibility of Contents and Language Feasibility of Physics Based Modules Multirepresentasi SMK Class X Even Semester.Journal of Learning and Science Education, No. 3. Vol 4: $177-182$.

13. Situmorang, Manihar. 2013. Development of High School Physics Textbook Through Innovation Learning and Integration Character Education To Improve Student Learning Outcomes. Proceeding Semirata FMIPA University of Lampung.

14. Suharjono. (2008). Prepare teaching materials so that lecture objectives are achieved more fun. Malang: Civil Department Faculty of Engineering UniversitasBrawijaya.

15. Widianingtiyas, L. 2015. The influence of multi-representation approach in physics learning to cognitive ability of high school students. Journal of Research \& Development of Physics Education, No. 1. Vol. 1: 31-38. 